PAPER • Full original article online Free

\title{
Evaluation Activity of Alanine Aminopeptidase $(A A P)$ in Patients with Renal Dialysis, Purification and Isolation of Isoenzymes
}

*Taghreed U. Mohammad \& Sawsan A. Mahdi \& Tammara A. Al-Kareim Directorate of Baghdad Education Karkh III, Ministry of Education, Baghdad, Iraq tagreedaloom@gmail.com

$$
\begin{aligned}
& \text { تقيم نشاط ألانين أمينوببتيداز (AAP) في المرضى الغسيل } \\
& \text { الكلوي وتنقية وفصل متناظرات الإنزيم } \\
& \text { *تغــــــد علوم مححمـــد \& سوسن عبد الحسين مهدي \& تمهارا احمد عبد الكريهم } \\
& \text { وزارة التربية، مديرية تربية بغداد الكرج الثالثة، بغداد، العراق }
\end{aligned}
$$

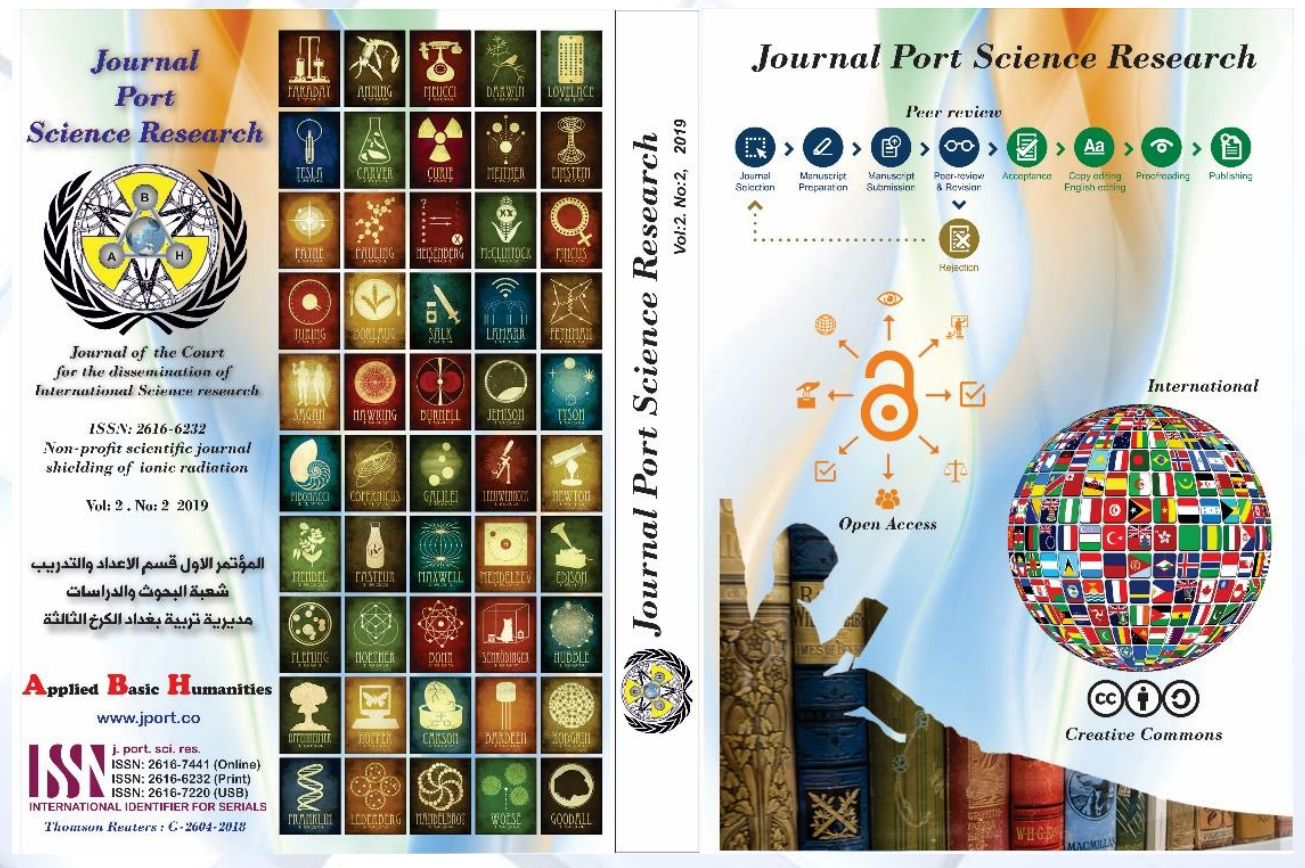

View for up https://jport.co

To cite this article: Published $2019 \bullet$ • $C 2019$ Bryant University United States of America Publishing Ltd 
Ministry of Education Iraqi Directorate of Education Baghdad Karkh III

First Conference Department of Preparation and Training Division of Research and Studies

وزارة التربية العراقية مليرية تربية بغداد الكرخ الثالثة المؤتمر الاول قسم الاعلداد والتلدريب ثعبة البحوث واللدراسات

\title{
Evaluation Activity of Alanine Aminopeptidase (AAP) in Patients with Renal Dialysis, Purification and Isolation of Isoenzymes
}

\author{
"Taghreed U. Mohammad \& Sawsan A. Mahdi \& Tammara A. Al-Kareim
}

Directorate of Baghdad Education Karkh III, Ministry of Education, Baghdad, Iraq

\author{
tagreedaloom@gmail.com
}

\begin{abstract}
Chronic renal failure is the progressive loss of function of kidney and patient requires a long treatment in the form of renal replacement therapy. Alanine aminopeptidase activity has been assayed in (70) patient's sera samples of both sexes, aged (25-70) years. The sample were divided in to two groups, the first group (G1) is of (35) samples before dialysis. The second group(G2) is of (35) samples after dialysis, as well as (30) sample of healthy as control group $(C)$. The result showed a significant increase ( $p>0.001)$ in general in the enzyme Alanine aminopeptidase in the serum of chronic renal failure patients (116.0 \pm 3.4$) \mathrm{U} / \mathrm{L}$ while the efficacy rate is $(105.5 \pm 3.4) \mathrm{U} / \mathrm{L}$ in healthy persons. Goal of the research was partial purified of enzyme from sera patients with chronic renal failure. by using two techniques: The first gel filtration chromatography packed with spadix G50 and giving $3.45 \%$ yield and 0.964 -fold purification. Two isoenzymes were obtained by using ion exchange chromatography and the purity degree of isoenzymes were $0.687(1.08 \%)$ and $2.539(1.04 \%)$ fold respectively. Also, the results showed a single band for isoenzymes following steps.
\end{abstract}

Keywords: Alanine aminopeptidase (AAP), Renal dialysis, Purification.

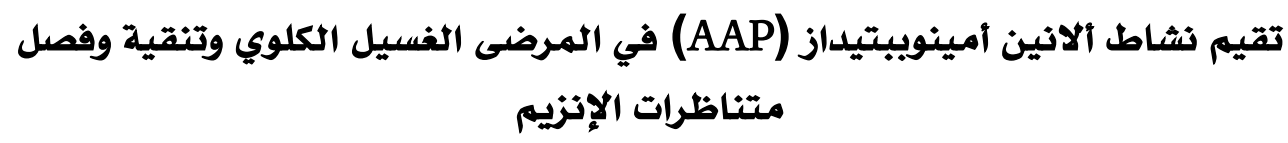

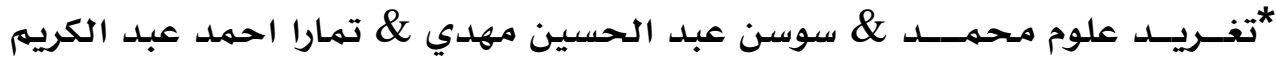

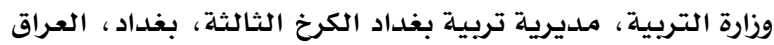

tagreedaloom@gmail.com

المستخلص يعد العجز الكلوي المزمن هو الفقدان التدريجي لوظيفة الكلى ولذلك يحتاخ المريض علاجا

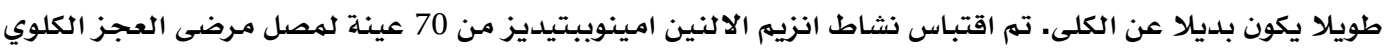

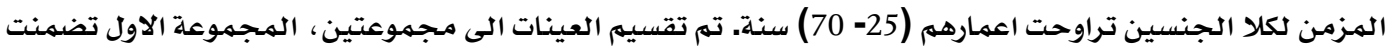

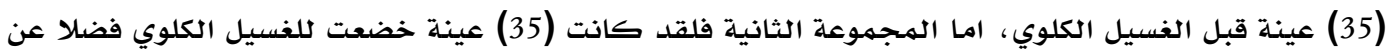

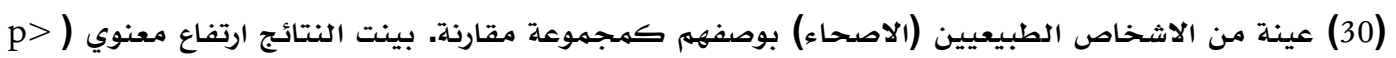

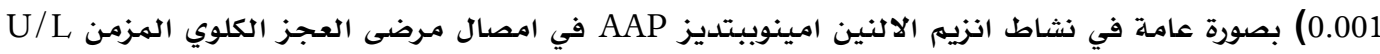

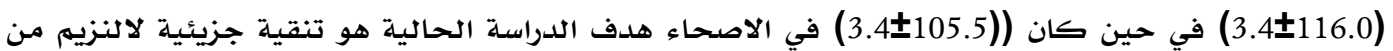

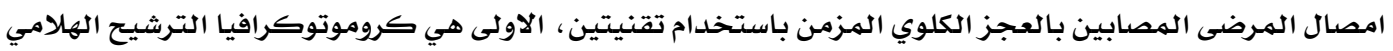
باستخدام السيفادكس G50 وقد بلغت عدد مرات التنقية (0.964) مرة ولنسبة انزيمية (3.45\%). الحصول على متناظرين باستخدام تقنية كروموتوغرافيا التبادل الايوني، كانت درجة التنقية للمتناظرين

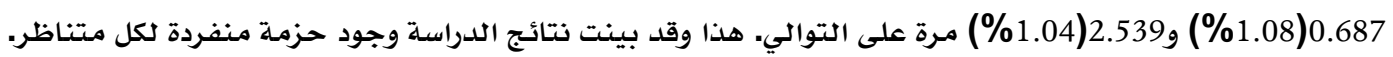

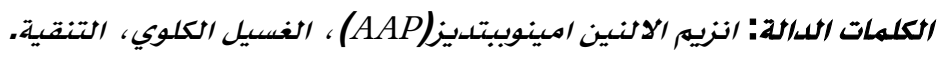

Mohammed, T. \& Mahdi, S. \& Al-Kareim, T. (2019). Evaluation Activity of Alanine Aminopeptidase (AAP) in Patients with Renal Dialysis, Purification and Isolation of Isoenzymes. Journal Port Science Research, 2(2), 265272. 


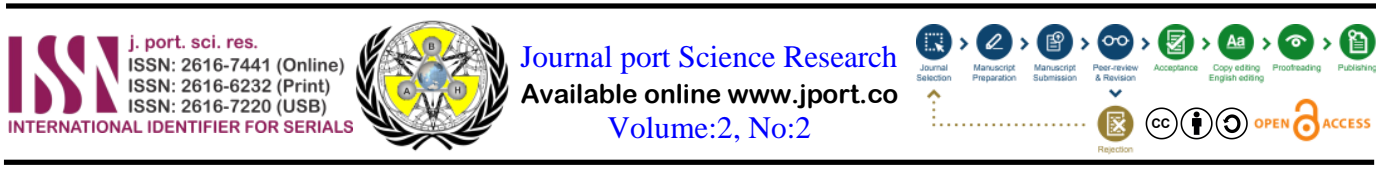

Introduction

Chronic kidney disease is an emergent worldwide public health problem. The increasing incidence of chronic renal failure warrants a need for an epidemiological approach to better understand the disease and its prevention. While statistics have been identified concerning world demographics, there is not enough information on how to better prevent and screen for this disease. There is evidence on the global distribution suggesting that chronic renal failure is a growing issue in developed and developing countries.[1] Renal Chronic Failure (CRF) this term is used to indicate the deficiencies and failures of the kidney function. Leading to general disruptions in the human body due to fluid retention and accumulation of nitrogenous waste. And harmful substances as a result of metabolic processes. Symptoms of renal impairment include accumulation of abnormal amounts of urea in the blood only, but to disturbances and imbalances in the hydrogen ion concentrations, water and salt balance, and accumulation of many other products as a result of metabolism.

This causes a state of internal poisoning and an increase in blood thinners resulting from the increase of harmful substances that the blood sheds through the kidneys such as uric acid and creatinine) [2]. Chronic renal impairment is a lack of kidney function due to chronic illness or syndrome due to consecutive and irreversible destruction of rental units (Nephron) [3]. CRF is characterized by a long, calm phase that lasts for several months with severe relapses that remain days or weeks. CRF is the end result of several diseases, and in some cases, there is no clear causative factor, as most acute renal failure is caused by renal disease and this indicates that most nephrons are present [4].

AAP (EC13.4.11.2), also known as CD13, is an exogenous peptide exopeptidase, which is preferred in the mammalian endocrine region. It has a wide range of mammalian bodies and has many different physiological functions within the human body [5]. AAP is an indicator for early renal damage [6]. On the other hand, there is a lot of evidence suggesting that AAP can be used to diagnose many cancers, playing a vital role in the invasion of malignancy and blood vessel [7]. Sensetivity and selectivity at the site a longer method is to determine which enzyme activity would contribute in the identification of many diseases that are associated with it [8].

The enzyme is widely spread in the kidney tissues, serum, mucous membranes of the small intestine [9-11] .Liver, pancreas, placenta and prostate in humans, not only the enzyme on the organs of the human body but is found in the tissues of some animals such as kidney tissue mouse [12], external cortex of the kidney of the rabbit, liver tissue, spleen, kidney, heart, pancreas, stomach, and lung of sheep, and pigs [13]. The kidney is one of the most abundant sources of enzyme, with its activity in the faculty of 10-15 times greater than the rest of the other members. Thus, the college is the main source of enzymes [14]. The aim of this investigation was evolution of the activity of the serum levels of AAP and the identification of isoenzymes from patients with CRF.

\section{Material and Methods}

Subjects The study is conducted during the period from 1st Oct. 2017 to the end of Dec 2017.The samples were collected from subjects attended Al-Karamh Hospital in Baghdad city. The study included (70) samples with chronic renal failure of both sex which were diagnosed by doctors specialists. The sample were divided in to two groups, the first group is of (35) samples before dialysis (G1). The second group is of (35) samples after dialysis (G2) aged (25-70), as well as (30) sample of healthy as control group (C), age range between (25-65) years.

Specimens Collection and Analysis Venous blood samples were drowning from each patient then transferred immediately to a clean dry plain tube. After removing the needle, the blood was allowed to clot for at least (10-15) min, at room temperature and then centrifuged for (15) min, at (3500 rpm). Serum is removed and assayed immediately and the samples were stored at $4{ }^{\circ} \mathrm{C}$ for the purpose of conducting the required measurements.

محمد ، تغـريــد علــهم. \& مهدي، سوسن عبد الحسين. \& الكريم تمارا احمد عبد. (2019). تقيم نشاط ألانين أمينوببتيداز

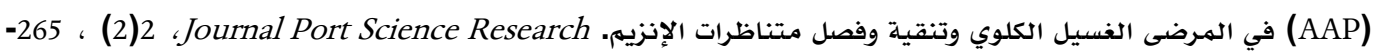


Methods

1) Assay of AAP activity in serum: AAP activity was measured in serum according to (Jung and Scholes., 1980) method [15]. Enzyme unit: is the amount of enzyme that catalyses' the reaction of $1 \mu \mathrm{mol}$ of substrate per minute.

2) Estimation of protein concentration: The total protein concentration was estimated in blood serum using a kit provided from a company (SPINREACT) depending Biuret method. (Tiets,N. W. et al., 1995).[16]

3) Purification of AAP from Serum of patients with chronic renal failure.

purification process had been done using the following steps: Precipitation by Using Ammonium Sulfate of Concentration 35\% The most frequent used method of protein precipitation is adding of non-organic salts like ammonium sulfate, or potassium phosphate. Large amount of water molecules will be bonded to ammonium sulfate when the protein is dissolved in water leading to decrease the amount of water molecules which are interferes with protein, therefore, protein molecules will be concentrated with each other and precipitate [17]. A solid-state ammonium sulfate of $(0.7 \mathrm{gm})$ was added gradually to a $(5 \mathrm{~mL})$ serum in a beaker with constant stirring at about $\left(4^{\circ} \mathrm{C}\right)$ for one hour till the solution became turbid. Then it was put in a centrifuge at speed (4000 rpm) for $(20 \mathrm{~min})$ to split the precipitate from the leach. Finally, the precipitate was dissolved in a less amount of buffer Tris$\mathrm{HCl} \mathrm{pH} \mathrm{7.8.} \mathrm{Activity} \mathrm{and} \mathrm{protein} \mathrm{concentration} \mathrm{were} \mathrm{measured.}$

Dialysis process had been done by putting the protein solution prepared in the previous step into a tightly wrapped cellophane bag from bottom and then it was wrapped tightly also from its top then the pipe was left in to a container which contains the buffer solution, Tris- $\mathrm{HCl}(0.05 \mathrm{M})$ ), this process was done at $\left(4^{\circ} \mathrm{C}\right)$ with constant stirring using magnetic stirrer. After finishing the dialysis process the final volume of the resultant solution was calculated. The amount of protein and enzyme activity were estimated.

Gel Filtration Two mL serum taken from dialysis bag was added slowly on the surface of the spadix G-50 column $(20 \times 1.5 \mathrm{~cm})$ and left for five minutes to be absorbed. Twenty fractions were collected by basing buffer solution, Tris- $\mathrm{HCl}(0.05 \mathrm{M}, \mathrm{pH} 7.8)$ through the column. Entire operation was carried out inside a refrigerator. Flow rate $(2 \mathrm{~mL} / \mathrm{min})$.

Ion Exchange Chromatography Two Millimeters of the fresh filtered serum sample were passed through a column of spadix ion exchange chromatography DEAE-Cellulose A 50 pre-equilibrated Tris- $\mathrm{HCl}(0.05 \mathrm{M}) \mathrm{pH} 7.8)$. The spadix ion exchange column of the size of $(20 \times 1.5 \mathrm{~cm})$ containing gradient concentration of sodium chloride $(0.1-0.4 \mathrm{M} / \mathrm{L})$. Entire operation was carried out inside a refrigerator. Flow rate $(2 \mathrm{~mL} / \mathrm{min})$.

SDS- PAGE Electrophoresis Sodium dodecyl sulfate SDS- polyacrylamide gel electrophoresis (10\%) was carried out according to Laemmle et al [18]. The purified enzyme was treated with $1 \%$ SDS and $\beta$-mercaptothion for 10 minutes at $100^{\circ} \mathrm{C}$ and loaded in wells. Samples stacking was done at $10 \mathrm{mM}$ and resolution was carried out at $15 \mathrm{~mA}$ constant current. Molecular weight standards were bovine serum albumin (66,000), ovalbumin (45,000), chymotrypsin $(25,000)$ (Sigma). After electrophoresis gel was stained in $0.25 \% \mathrm{w} / \mathrm{v}$ Coomassie brilliant blue (R-250) prepared in 50\% v/v methanol and $10 \% \mathrm{v} / \mathrm{v}$ acetic acid. The gels were distained by passive diffusion of dye in $50 \% \mathrm{v} / \mathrm{v}$ methanol and $1 \%$ acetic acid after changing the detaining solution for 2-3 times.

Statistical Methods analysis was used to show the mean and standard error deviation of variables. The significance of difference between mean values was estimated by student T-Test. The probability $\mathrm{P}>0.05=$ non- significant. ANOVA test was used to show the differences between variables of differentiated groups. The data were processed with the software package SPSS (statistical package for social sciences) Ver.25 and Microsoft Excel version 2007 [19].

Mohammed, T. \& Mahdi, S. \& Al-Kareim, T. (2019). Evaluation Activity of Alanine Aminopeptidase (AAP) in Patients with Renal Dialysis, Purification and Isolation of Isoenzymes. Journal Port Science Research, 2(2), 265272. 


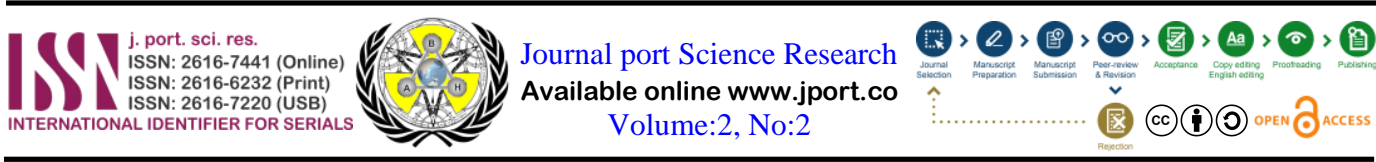

Result and Discussion

Table (1) shows the mean $\pm \mathrm{SE}$ and $\mathrm{P}<$ value of the AAP activity in sera of patients with CRF (before and after renal dialysis) and healthy. The result in table (1) shows a highly significant increase in the AAP activity in the patients with CRF after renal dialysis G2 (116.0 $\pm 3.0 \mathrm{U} / \mathrm{L})$ when compared to healthy $\mathrm{C}(105.5 \pm 3.4 \mathrm{U} / \mathrm{L})$. While there is no significant difference in the activity of the enzyme in the patients with $\mathrm{CRF}$ before renal dialysis(G1).

Table (1): Mean $\pm S E$ of AAP activity in the sera of patients with CRF (before and after renal dialysis) and healthy.

\begin{tabular}{|c|c|c|c|c|c|c|c|c|}
\hline Groups & 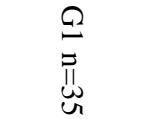 & $\begin{array}{l}\text { N } \\
\stackrel{\|}{\|} \\
\stackrel{\sim}{\prime}\end{array}$ & $\begin{array}{l}\Omega \\
\stackrel{]}{1} \\
\stackrel{2}{0}\end{array}$ & $\begin{array}{l}\overrightarrow{0} \\
\stackrel{0}{\Xi} \\
\overrightarrow{\|}\end{array}$ & \multicolumn{4}{|c|}{$P$-Value } \\
\hline Parameter & $\pi$ & $\pi$ & $\pi$ & $\pi$ & G1vs. 2 & G1vs C & G2vs.C & Total \\
\hline AAP U/L & $108.4 \pm 4.7$ & $132.7 \pm 5.4$ & $105.5 \pm 3.4$ & $116.0 \pm 3.0$ & $P<0.001$ & $P>0.05$ & $P<0.001$ & $P<0.001$ \\
\hline
\end{tabular}

It appears as if diagnostic enzymology in blood plasma offers little in the recognition and differential diagnosis of renal diseases, with the exception perhaps of the renal infarct. The results rule out simple hemoconcentration as the cause for enzyme activity increases as has been found in the acute decreased of the plasma volume. Blood cell, which are exposed to a considerable mechanical stress during hemodialysis and the diseased kidneys could be excluded as possible sources of the enzymes. Their respective enzyme activity patterns were inconsistent with the pattern of activity increase in plasma. There is further and direct evidence against the diseased kidneys as enzyme source the activity change in plasma following hemodialysis were the same before and after bilateral nephrectomy .[20] Activity increases of enzymes following hemodialysis could theoretically be caused by the removal of inhibitors. It was confirmed by the present authors that in in vitro dialysis of serum from patients and healthy persons against the dialysis medium had no significant effect on the enzyme activity.[21]

Although the plasma volume remains constant in most instances during hemodialysis, the organism loses intracellularly and interstitially retained water. It is conceivable that with the redistribution of fluid, enzymes are transported via the lymph from the interstitial into the intravascular space where they accumulate during hemodialysis. It is known from animal experiments 12 that the enzyme patterns of the lymph (as the reservoir of the interstitial fluid) differs considerably from that of the blood plasma. An increased flux of enzyme containing lymph into the plasma must therefore result in changes of the intranasal enzyme activity pattern. Although there is no evidence at present, another reason for the observed effect should be considered, namely a temporary inhibition of the elimination of enzymes during hemodialysis.[20]

Table (2) present the isolation and partial purification of AAP enzyme and isoenzymes from serum patients with CRF. the AAP activity reached (107) U/ L by using ammonium sulphate saturation (35\%). The enzyme was partially purified by using dialysis method with Tris baffler solution $(\mathrm{pH}=7.8)$, the purity fold of AAP was 1.195 folded with a yield $(7.53 \%)$, while the purity degree was 0.989 flood with a yield (3.45\%) using spadix G- 50 column chromatography. This enzyme shows a single peak in figure 1 and the AAP activity reached $26.97 \mathrm{U} / \mathrm{L}$. The purification by ion exchange chromatography technique offered several distinct advantages over other conventional methods of separation of serum isoenzymes. This enzyme was purification by using DEAE-cellulose A-50. Two isoenzymes were obtained as shown in figure (2) The purity degree of isoenzyme I was 2.635 folded with yield $(1.08 \%)$ and isoenzyme II with 0.659 -fold with yield (1.04\%)

محمدد ، تغـريــد علـــه. \& مهدي، سوسن عبد الحسين. \& الكريم تمارا احمد عبد. (2019). تقيم نشاط ألانين أمينوببتيداز

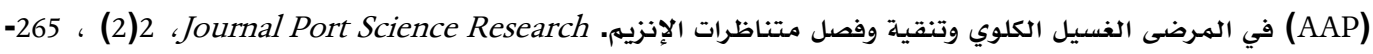


Table (2): Purification steps of AAP from patients with CRF.

\begin{tabular}{|c|c|c|c|c|c|c|c|c|}
\hline Step & 胥 & 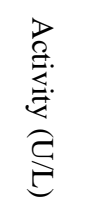 & 密 & 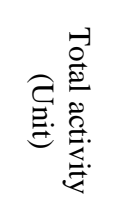 & 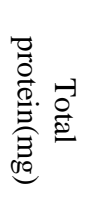 & 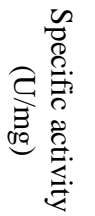 & 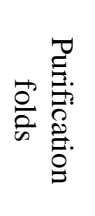 & $\frac{\nwarrow}{\frac{d}{2}}$ \\
\hline $\begin{array}{l}\text { Crude } \\
\text { serum }\end{array}$ & 10 & 156 & 608 & 1.56 & 6.08 & 0.256 & 1 & 100 \\
\hline $\begin{array}{l}\text { Ammonium } \\
\text { sulfate }\end{array}$ & 5 & 107 & 556 & 0.535 & 2.78 & 0.192 & 0.750 & 34.29 \\
\hline Dialysis & 5 & 32.5 & 160 & 0.117 & 0.8 & 0.146 & 0.750 & 7.53 \\
\hline $\begin{array}{c}\text { Gel } \\
\text { filtration }\end{array}$ & 2 & 26.97 & 107 & 0.053 & 0.214 & 0247 & 0.964 & 3.45 \\
\hline \multicolumn{9}{|l|}{$\begin{array}{c}\text { Ion } \\
\text { exchange }\end{array}$} \\
\hline Iso.I & 2 & 8.45 & 48 & 0.0169 & 0.096 & 0.176 & 0.687 & 1.08 \\
\hline Iso.II & 2 & 8.125 & 12.5 & 0.01625 & 0.025 & 0.65 & 2.539 & 1.04 \\
\hline
\end{tabular}

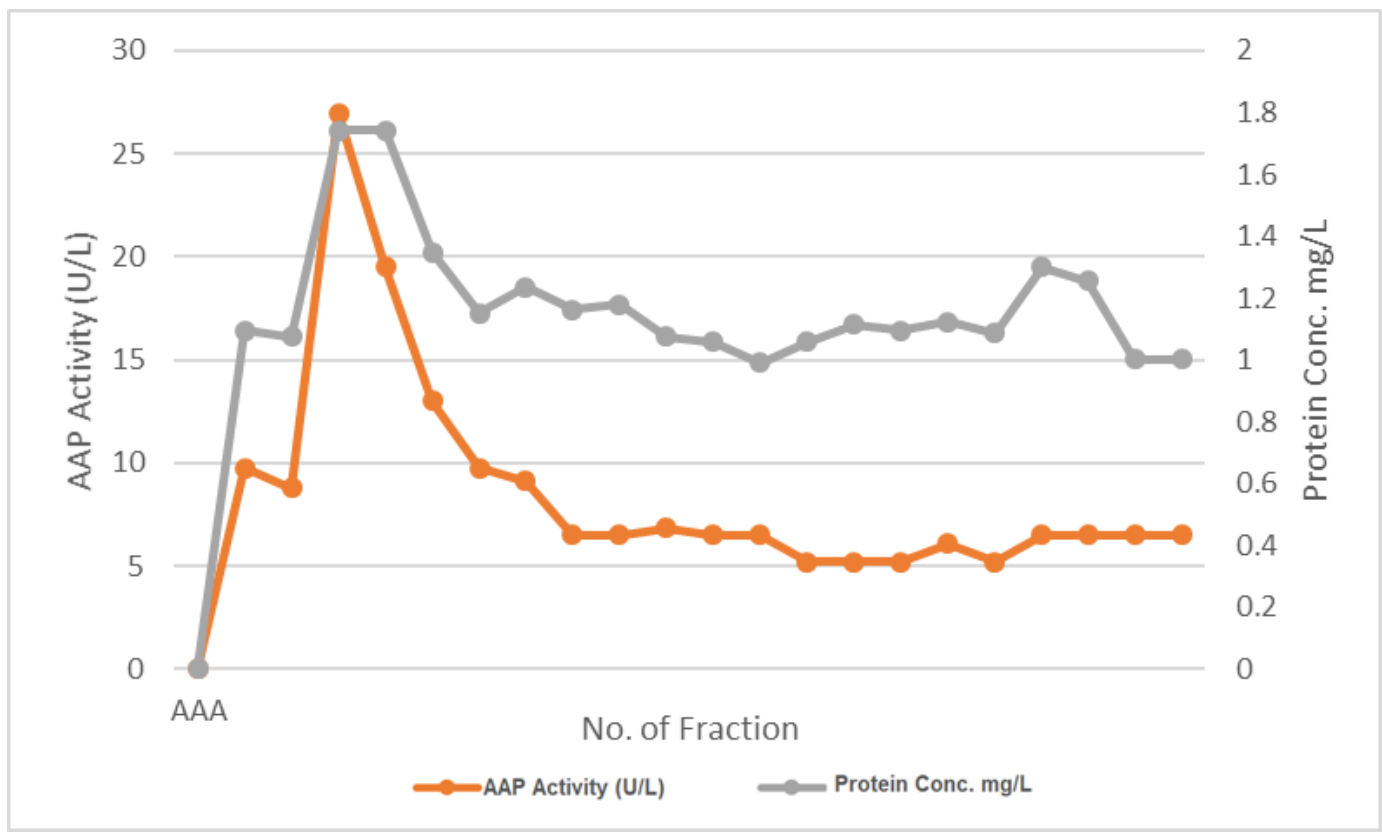

Figure (1): Elution of the gel -filtration chromatography of sephadex G-50 fraction plot of protein content values and AAP activity with sera of CRF

The literatures indicate that three isoenzymes were separated from water buffalo kidney by using DEAE - cellulose column followed by gel filtration chromatography on sophistry 1 S-300 column and pancreas AAP was resolved upon purification with ion exchange chromatography into three isoenzymes [22].

Mohammed, T. \& Mahdi, S. \& Al-Kareim, T. (2019). Evaluation Activity of Alanine Aminopeptidase (AAP) in Patients with Renal Dialysis, Purification and Isolation of Isoenzymes. Journal Port Science Research, 2(2), 265272. 

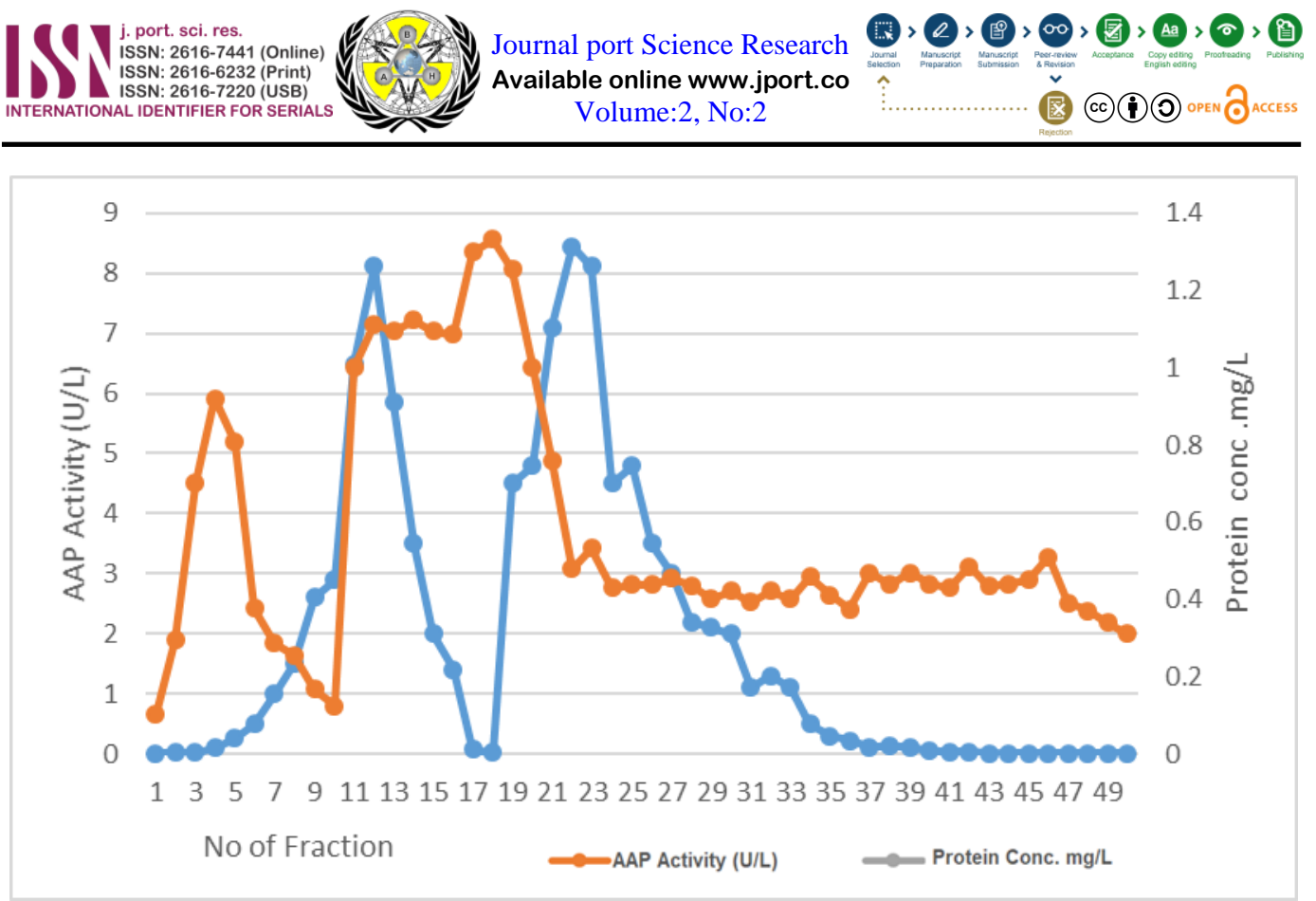

Figure (2): Elution of the ion exchange chromatography of DEAE cellulose fraction plot of protein content values and AAP activity with sera of $C R F$

The literatures indicate that three isoenzymes were separated from water buffalo kidney by using DEAE - cellulose column followed by gel filtration chromatography on sophistry 1 S-300 column and pancreas AAP was resolved upon purification with ion exchange chromatography into three isoenzymes .[22]

Gel electrophoresis was used to confirm the purity of the isolated isoenzymes by using sodium dodecyl sulfate - polydactyl amide gel electrophoresis (SDS- PAGA) which appeared as a single band. figure (3).

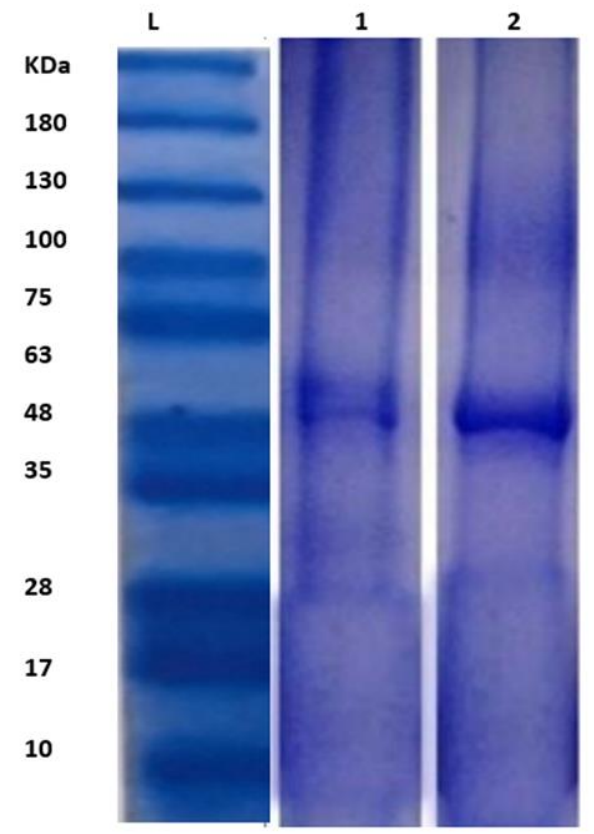

Figure (3): Electrophoresis of isolation Alanine aminopeptidase

محمد ، تغـريــد علـــم. \& مهدي، سوسن عبد الحسين. \& الكريم تمارا احمد عبد. (2019). تقيم نشاط ألانين أمينوبيتيداز

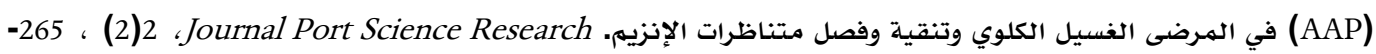




\section{References}

[1] B.SRINIVAS, S.BALAJI, M. N. B. Y. S. R. (2015). REVIEW ON PRESENT AND ADVANCE MATERIALS FOR SOLAR CELLS. International Journal of Engineering Research- Online, 3, 178-182.

[2] Islam, T. (2014). Household level innovation diffusion model of photo-voltaic (PV) solar cells from stated preference data. Energy Policy, 65, 340-350. https:// doi.org/10.1016/j.enpol.2013.10.004

[3] Castañer, L., Bermejo, S., Markvart, T., \& Fragaki, K. (2012). Energy Production by a PV Array. In Practical Handbook of Photovoltaics (pp. 645-658). Elsevier Ltd. https://doi.org/10.1016/B978-0$\underline{12-385934-1.00018-0}$

[4] Sugathan, V., John, E., \& Sudhakar, K. (2015, August 12). Recent improvements in dye sensitized solar cells: A review. Renewable and Sustainable Energy Reviews. Elsevier Ltd. https:// doi.org/10.1016/j.rser.2015.07.076

[5] Shu, N., Kameda, N., Kishida, Y., \& Sonoda, H. (2006). Experimental and Theoretical Study on the Optimal Tilt Angle of Photovoltaic Panels. Journal of Asian Architecture and Building Engineering, 5(2), 399-405. https:// doi.org/10.3130/jaabe.5.399.

[6] Zang, H., Guo, M., Wei, Z., \& Sun, G. (2016). Determination of the optimal tilt angle of solar collectors for different climates of China. Sustainability (Switzerland), 8(7), 1-16. https: / / doi.org/10.3390/su8070654

[7] Kaldellis, J., Kavadias, K., \& Zafirakis, D. (2012). Experimental validation of the optimum photovoltaic panels' tilt angle for remote consumers. Renewable Energy, 46, 179-191. https:// doi.org/10.1016/j.renene.2012.03.020.

[8] Shu, N., Kameda, N., Kishida, Y., \& Sonoda, H. (2006). Experimental and Theoretical Study on the Optimal Tilt Angle of Photovoltaic Panels. Journal of Asian Architecture and Building Engineering, 5(2), 399-405. https:// doi.org/10.3130/jaabe.5.399.

[9] Razykov, T. M., Ferekides, C. S., Morel, D., Stefanakos, E., Ullal, H. S., \& Upadhyaya, H. M. (2011). Solar photovoltaic electricity: Current status and future prospects. Solar Energy, 85(8), 1580-1608. https:// doi.org/10.1016/j.solener.2010.12.002.

[10] Kacira, M., Simsek, M., Babur, Y., \& Demirkol, S. (2004). Determining optimum tilt angles and orientations of photovoltaic panels in Sanliurfa, Turkey. Renewable Energy, 29(8), 1265-1275. https:// doi.org/10.1016/j.renene.2003.12.014

[11] Esraa Al-Sarray \& Ali Jabbar. (2019). Investigate the Ability of the Eggshell to Attenuate the Gamma and Beta Rays as Compared with Composite FeSO4.7H2O. Nuclear Science, 3(1), 16-22. https: / / doi.org/10.11648/j.ns.20180301.13

[12] Eltbaakh, Y. A., Ruslan, M. H., Alghoul, M. A., Othman, M. Y., Sopian, K., \& Fadhel, M. I. (2011, April). Measurement of total and spectral solar irradiance: Overview of existing research. Renewable and Sustainable Energy Reviews. https:// doi.org/10.1016/j.rser.2010.10.018.

[13] Xu, R., Ni, K., Hu, Y., Si, J., Wen, H., \& Yu, D. (2017). Analysis of the optimum tilt angle for a soiled PV panel. Energy Conversion and Management, 148, 100-109. https:// doi.org/10.1016/j.enconman.2017.05.058.

Mohammed, T. \& Mahdi, S. \& Al-Kareim, T. (2019). Evaluation Activity of Alanine Aminopeptidase (AAP) in Patients with Renal Dialysis, Purification and Isolation of Isoenzymes. Journal Port Science Research, 2(2), 265272. 
j. port. sci. res.
ISSN: 2616-7441 (Online)
ISSN: $2616-6232$ (Print)

[14] Shnishil, A. H., Chid, S. S., Yaseen, M. J., \& Alwana, T. J. (2011). Influence of air mass on the performance of many types of PV modulus in Baghdad. In Energy Procedia(Vol. 6, pp. 153-159). Elsevier Ltd. https: / / doi.org/10.1016/j.egypro.2011.05.018.

[15] Ebrahiem, S. A., Falih, E. H., Mahdi, A. M., Shaban, A. H., \& Majeed Mahdi, H. A. (1968). Indoor $222 \mathrm{Rn}$ measurement and hazards indices in houses of Al-Najaf province - Iraq Rn Measurement and Hazards Indices in Houses of Al-Najaf Province - Iraq. AIP Conference Proceedings, 030003. https: / / doi.org/10.1063/1.5039190

[16] Lee, C. Y., Chou, P. C., Chiang, C. M., \& Lin, C. F. (2009, April 27). Sun tracking systems: A review. Sensors. https:// doi.org/10.3390/s90503875. 